\title{
THE SYSTEM OF THE TWO TRUTHS IN THE PRASANNAPADĀ AND THE MADHYAMAKĀVATĀRA: A STUDY IN MĀDHYAMIKA SOTERIOLOGY
}

\begin{abstract}
Although the world may quarrel with me, I have no quarrel with the world: that which is considered to exist in the context of the world I also assert as existent; and that which is considered not to exist in the world $I$ also assert as non existent.

Samyuttanikāya, 22.64.103; as cited by Candrakirti in Prasannapadā, p. 370, and Madhyamakāvatāra, p. 179.
\end{abstract}

\section{INTRODUCTION}

Throughout the Madhyamakasästra, nirvāna is described in very uncompromsing terms. Nirvana is the ultimate truth, ${ }^{1}$ it is reality (tattva). ${ }^{2}$ Nirvāna is not dependent on anything whatsoever, it is entirely at peace and absolutely unsusceptible to conceptualization. ${ }^{3}$ When the mind has become inactive, when the business of the world with its dichotomy between subject and object has come to a complete standstill because the chaos of birth, old age and death is no more, then one is said to have arrived at the final beatitude of nirvanna. ${ }^{4}$ Candrakirti states quite clearly that "it is utterly impossible for nirvana to be attained by any path that has to do with samsāra, the beginningless cycle of birth and death". ${ }^{5}$ Whereas samsāra is ignorance, nirvana is the ultimate truth. ${ }^{6}$ Samsära is bewilderment, passion and enmity, and nirväna is complete tranquility. Understood in this way, as final release from all the misery of birth, decay and death, nirvanna is the goal of the Buddhist Path, the raison d'être of Buddhist philosophy and practice, and the ultimate concern of Nāgārjuna's Madhyamakaśästra. ${ }^{7}$ And yet, if nirvāna is an absolute denial of samsāra, then how are we to interpret kārika XXV. 19? -

Samsära is not the slightest bit different from nirväna; nor is nirvāna the slightest bit different from samsära.

Like much of what Nāgārjuna wrote, this stanza appears to stand in absolute 
defiance of the tradition which preceded the development of Mādhyamika. Worse yet, kärika XXV. 19 and others like it lend themselves to no facile interpretation even within the context of the Mādhyamika system itself.

As we shall see in what follows, the words nirvāna and samsāra are representative of two broad divisions of technical terminology within the Madhyamakasästra. On the one hand, the term samsära quite naturally aligns itself with other words like avidyā, svabhäva and duhkha, all of which seem to coalesce around the generic concept of samvrti, the relative or conventional truth. On the other hand, nirvāna, süunyatā, śänti and many other terms from the second division are grouped very conveniently under the rubric of paramärthasatya, the ultimate truth. Such terminology is used to illuminate various particular nuances of meaning within each of the two principal divisions. For instance, whereas samsära and nirvâna are primarily of soteriological significance, svabhāva and śūnyatā refer to ontological issues, and the terms $d u h k h a$ and śänti denote two specific affective states. Samvrti and paramärtha are not necessarily the most important concepts within these two classes of terminology, but they are in a sense the most general or unmarked terms, and therefore they are especially significant for the purposes of philosophical investigation. Any one of these words carries with it connotations stemming from its association with the other words of its class, yet this is perhaps most evident in the case of samvrti and paramartha, for each one clearly reflects the entire range of meaning associated with its respective division. This should become evident when we take a closer look at the system of the two truths.

\subsection{The Nature of the Problem}

If we were simply confronted with these two distinct classes of terminology, then the situation would not be nearly so complex as it actually is. Upon first glance, both divisions seem to represent very neatly packaged groups of concepts: samsāara is bondage, nirvāna is liberation; svabhāva is unreality and sünyatā is reality; samvrti is error or falsehood and paramärtha is truth. One can locate literally hundreds of passages in the literature of the Mādhyamika to support this type of strictly dualistic understanding of these words. However, there are many places, as in kärika XXV. 19, where the boundry between the two groups seems to blur or to break down altogether, and these places serve as focal points for a great deal of the philosophical controversy which has surrounded the Mãdhyamika system since the time 
of Nāgārjuna. Over the years, such passages have been a thorn in the side of many of Nāgãrjuna's apologists, and at the same time it is certain that conundrums like the one presented in kārika XXV. 19 are the vital centers of Mādhyamika thought. They cannot be summarily dismissed, and still it seems as if no single approach is adequate to explain their significance within the pattern of the system as a whole. Clearly the issues involved are not merely of passing interest, since one may easily argue that it is to just such lines as those quoted above from kärika XXV. 19 that we must look in order to find solutions to several very important problems.

\subsection{The "Linguistic" Interpretation of Mädhyamika}

Most recently, a sort of linguistic analysis has shown itself to be one especially fruitful method of unravelling the paradox presented by these passages. With specific reference to kärika XXV. 19, D. Daye summarizes the conclusions of this linguistic approach:

The above suggest that such distinctions and limits are merely context restricted but still seductive bits of language. One is also led to the suggestion that the distinctions of language (witness nirvāna and samsāra) are merely and only internally consistent and are only pragmatically correlated with our perceptions. This is quite enough and it is quite reasonable. However, such a view entails no non-circular conclusion about anything which is said to escape the warm boundries of human care (duhkha) and the bewitching motherhood of talking (samvrtisatya). ${ }^{8}$

According to this analysis, the philosophy of the Mādhyamika embodies a special meta-language which has the particular capability to "diminish the magical attachments to and obscurations of our inner language". 9 Elsewhere in the same article Daye writes:

The implications of the ontological status of language-descriptions and their correlations with the publiclly known objects in the furniture of the world lead one to the conclusion that all ontological descriptions are merely pragmatically useful but provisional fictions. They guarntee only that what is known is simply (and tautologically) consistent with what is known. That is, no conclusions about the transcendental or ultimate nature (yathäbhütam) are authorized by statements verified by public or private observation: rather, what can be known (explicitly) is to be known. ${ }^{10}$

\section{3. "Reality as Fiction" - A Soteriological Approach}

There is little question that Daye's interpretation is justified on the basis of the Mādhyamika's own concept of "dependent designation" (prajñaptir 
upādāya), and I have taken this analysis as my point of departure for what follows. However, as we shall soon discover, the works of early Indian philosophers are not always so explicit as one might desire with respect to these issues, and this is especially true in the case of questions regarding the ontological status of the world. Precisely what are the implications of this view of language and conceptual thought, attributed to the Mãdhyamika, which asserts that "all ontological descriptions are merely pragmatically useful but provisional fictions"? In an article entitled "Everyday Reality as Fiction - A Mādhyamika Interpretation" "Charles Crittenden makes the following very interesting observation with respect to the system of the two truths:

I think ... that this distinction is best explicated in terms of a difference in the standpoint one can take in regard to the world and the kinds of attitude which are possible given these standpoints. To try and interpret the two-truth idea ontologically would not seem promising: for on the Mādhyamika view, at least, there is not some transcendental reality over and above everyday reality which could be denoted by expressions in the higher truth. Rather this and the lower truth both concern the familiar world; hence some non-metaphysical approach seems best and certainly the notion of an attitude, already present in the analysis of the motivations of the reality-as-fiction proposal, suggests itself. 12

Elsewhere in the same article Crittenden goes on to say,

Buddhism is after all not only, or even especially, a set of philosophical doctrines but is intimately connected to the practice of meditation and the experiences thereby sought for. Someone who adopted typical Buddhist philosophical theories but who had no interest in meditational practice or in certain sorts of experience would hardly qualify as Buddhist - a point made again and again in Buddhist literature. And certainly much of Buddhist theorizing can be regarded as attempting to articulate concepts and principles explaining and justifying meditation and the kinds of experience which this aims at producing. ${ }^{13}$

What is the nature of the relationship defined by samvrti and paramartha? What exactly is given in the context of mundane experience (loka-samvrti)? Finally, how is this content analyzed by the Mãdhyamika, and how is it transformed, if at all, through the experience of nirvanna? Over the course of the next several pages I intend to examine Candrakirti's two major philosophical treatises, and by means of this examination I hope to reveal the degree to which his work demonstrates an awareness of these questions not simply as linguistic problems, but also - and primarily, I believe as soteriological issues. 
The Mādhyamika's concept of language implies a particular attitude towards the world, or better yet, a particular way of seeing this world as it is (yathābhütam). As a Buddhist philosopher, Candrakīrti not only assumes that such a yogic vision is indeed possible, but he clearly states that he has taken this assumption as the touchstone for his own philosophical analysis. ${ }^{14}$ Therefore, by taking a closer look at these texts I expect to accomplish two primary tasks: first, to clarify the original terminology of this literature; and second, to develop an appreciation of the Mādhyamika's concept of language within the context of his own fundamental belief in the possibility of liberation through the yogic vision of phenomena as empty of intrinsic being.

\section{NIHILISM, ETERNALISM AND THE MIDDLE WAY}

When we turn to the history of the controversy that has surrounded Nāgārjuna's philosophy, it is immediately evident that debate has focused time and time again upon a few crucial topics, and from among these topics there is certainly none that has inspired more elaborate and heated rhetoric than has the issue of nihilism. The spectre of nihilism obviously haunted Nāgārjuna's work from the beginning, and despite Candrakīti's spirited efforts to dismiss the problem, one is perhaps never really convinced that Candrakīti himself, after all, did not do more than his share to maintain a comfortable place for this unwanted guest. To start with, let us investigate the nature of the allegations raised against the Mādhyamika by his opponents, so the issue is acutally not that of nihilism alone; rather it has to do with the problem of nihilism and eternalism versus the Middle Way.

It is not difficult to isolate the source of these charges of nihilism. Throughout the Madhyamakaśāstra Nāgārjuna rejects every possible argument designed to substantiate the existence of apparent phenomena. If it is true that the Mādhyamika denies the existence of all that contributes to mundane experience, then his opponents may well be justified in their fear that such a position differs very little from the nihilist's rejection of all meaning whatsoever. Indeed, by far the most serious accusation of all was brought to bear against the Mādhyamika by his own fellow Buddhists:

If everything is empty, then nothing comes into or goes out of existence. Consequently, for you the four noble truths themselves do not exist 15 ... and by expounding [ the emptiness of all things] you reject the three jewels. ${ }^{16}$ 
It is difficult to avoid reading the denial of being ( $b h \bar{a} v a)$ as anything other than an acceptance of non-being ( $a b h \bar{a} v a)$ with all the dire implications of such a position; and yet, according to Nāgãrjuna and Candrakīrti, this represents a grave misunderstanding of the Mādhyamika's brand of negation. Being is not rejected in favor of non-being, but rather being and non-being are both denied in order to provide access to a seperate vantage point from which the world is seen to be neither absolutely real nor absolutely false. Moreover, it is important to note the particular way in which Nãgārjuna and Candrakirti countered the accusation leveled just above:

In response to this we contend that you do not know the purpose (prayojana) of emptiness, nor emptiness itself, nor its meaning. And therefore you are lost. ${ }^{17}$

In his commentary to this stanza Candrakirti explains the "purpose" of emptiness in the following way:

Through your own misconceptions you, sirs, have mistakenly assumed that emptiness is non-existence, and directing such accusations against us . . you become the victims of great distress and so you are totally lost. What this means is simply that you are slain by a variety of pure fantasies ... And therefore, because you do not comprehend the intrinsic nature of things as they are, your characterization [of emptiness] is senseless and bears no relationship whatsoever to our own explanations. Then what is the purpose of emptiness? This is stated in [Madhyamakaśastra, XV. 1], the chapter dealing with examination of the self: "Liberation follows from the destruction of both karmic action and the afflictions. Karmic action and the afflictions arise from reified notions (kalpana ) [of real and unreal things], and these are produced from conceptual diffusion. Conceptual diffusion, however, ceases in emptiness." This being the case, emptiness is taught in order to effectively tranquilize the process of conceptual diffusion (prapañca), and therefore the purpose of emptiness is the tranquilizing of all conceptual diffusion. On the other hand, in imagining that emptiness means non-existence you, sirs, actually strengthen the net of conceptual diffusion and do not in the least understand the purpose of emptiness. ${ }^{18}$

The purpose of emptiness is clearly soteriological. Further along in this same section of his commentary Candrakirti reminds us that the term "emptiness" is itself simply a linguistic device, but he seems to feel that we would be less likely to lose touch with this fact if we understood the concept in a broader context which took into account the soteriological purpose of the Madhyamakasasastra.

Candrakīti holds this distinction to be most critical: whereas he conceives of "eternalism" (śäsvatavāda) as the reified concept of "being" (bhāva) and nihilism (ucchedaväda) as the reified concept of "non-being" (abhäva), 
the Middle Way is distinguished from both of these as a third alternative which is presented as the single philosophically viable description of the true nature of phenomena.

How are we to approach the notion of the Middle Way? Perhaps the best advice at this juncture comes from Nāgãrjuna, when he tells us that "those who do not understand the distinction between the two truths cannot possibly understand the profound truth of the Buddha's teaching". ${ }^{19}$ Therefore, we shall proceed with an investigation of the system of the two truths.

\section{THE SYSTEM OF THE TWO TRUTHS}

All entities bear a dual nature, which corresponds to the entity as apprehended by either correct or incorrect perception. The object revealed by correct percpetion is reality (tattva), while that revealed by incorrect perception is referred to as the Truth of the Screen (samvrti-satya). ${ }^{20}$

\subsection{Samvrti}

\subsubsection{General characteristics of the "screened truth". A very concise} introduction to the nature of this "screen" is provided in the 24th chapter of the Prasannapad $\bar{a}$, where Candrakirti mentions four general characteristics of samvrti. ${ }^{21}$

(1) Samvrti is complete and total covering (samantâdvaranam). This means that the phenomena of the world are not what they seem to be; they are false (mosa) and misleading, because they do not actually exist as discrete entities. Although we take the contents or our perceptions for granted, when closely examined through the medium of the Mãdhyamika dialectic our beliefs about the world prove to be riddled with contradiction. So-called solid objects dematerialize under the force of the dialectic.

(2) Samvrti is the ignorance (avidy $\bar{a}$ ) that arises from the total obscuration of the reality of individual entities. "Precisely because it obstructs [awareness of] the intrinsic nature [of all phenomena], delusion is a screen (samvrti); and on its account what is merely fabricated appears as real." 22 Ignorance is the source of suffering in the world,,$^{23}$ for it is said to be conjoined with all the other afflictions of covetousness, anger, pride, attachment to false theories, and doubt or cynicism. This is samvrti as the misery of samsära. ${ }^{24}$ 
(3) Samvrti is the circumstance that all things exist in dependence on each other; that is to say, that they are founded on each other in a relationship defined by absolute reciprocity. Each of the elements of mundane experience is dependent for its own existence on a collocation of causes and conditions. This is samvrti as dependent origination (pratityasamutpäda).

(4) Samvrti is characterized as the signs and symbols (samketa) which make possible the business of the world (loka-vyavahära). This is also samvrti as samsära, not as suffering, however, but rather in the affectively neutral sense of language and conceptual thought.

\subsubsection{Conventional knowledge. Candrakirti accepts four valid means of} knowledge (pramāna) associated with samvrti: ${ }^{25}$ (1) inference (anumāna); (2) authority (ägama); (3) analogy (upamāna); and (4) sense perception (pratyaksa). These pramāna-s are totally dependent on the objects which they reveal, and the objects are equally dependent on them:

Insofar as there are means of knowledge, there are objects of knowledge; and insofar as there are objects of knowledge, there are means of knowledge. It is certain that neither the means nor the object of knowledge can be established as existent in and of itself. ${ }^{26}$

The primary significance of this definition of pramana is that for Candrakirti neither "the world" (loka) nor any other single entity (bhāva) can be absolutely affirmed. There can be no "being-in-and-of-itself" (bhävasvabhāva), nor any means of knowing such a substance even were it to somehow exist. This effectively constitutes a refutation of "eternalism" defined as any sort of substance ontology that entails a reification of the objective referent posited by a word or concept. It also seems to imply that neither the world as a whole nor any other individual entity can be absolutely negated: there can be no valid reification of the concept of "non-being" (abhāvasvabhāva); that is, non-being can only be conceptualized in opposition to being. This is a very important point for Candrakirti, and one which he emphasizes by stating that "it is on this account that the world must exist just as it is perceived". ${ }^{27}$ A third and final ramification of this notion of pramāna is brought out in Madhyamakāvatāra, VI.31:

Mundane experience is not authoritative in every respect, and therefore it does not contradict any dealings with reality. However, if an object of mundane experience is negated through recourse to [a metaphysical argument used] in the context of 
mundane experience, then the testimony of mundane experience may itself effectively be used to contradict that negation.

Essentially this is a restatement of the first two points already mentioned above, since it is nothing more than a restriction placed on all four pramāna-s which limits their authority to the realm of samvrti. In the auto-commentary, however, the implications of this kärika are made clear. There we are told that one may not legitimately negate the objects given in mundane experience by relying on an argument that is drawn from testimony supposed to lie outside the socio-linguistic context defined by this common experience. Only the testimony of mundane experience itself may be effectively used for this purpose, and this is enough for the Mãdhyamika. Candrakirti writes in the summary to his position on this issue:

One accepts "production from another" on the consensus of mundane experience, and thus he avoids being contradicted by the world. On the other hand, according to mundane experience it is also the case that there is not production from another, and one may desire from this point of view to refute production from another, which would then entail no contradiction by the world. ${ }^{28}$

This is the method of the dialectic, which claims to reveal the true nature of samvrti not by resorting to any substance ontology or metaphysical position, but simply by drawing attention to the fact than certain basic notions taken for granted by the world, as for instance the idea of causality, are logically untenable. We will have occassion to explore the implications of this approach to negation in greater detail, ${ }^{29}$ but first we must briefly review the types of samvrti that are found in Candrakirti's writings.

\subsubsection{The types of samvrti. Madhyamakāvatära VI. 25 sets forth the two principal divisions of samvrti:}

That which, within the realm of mundane experience, is apprehended by any of the six unimpaired sense faculties is true according to mundane experience, while any remaining reified concepts are false according to this same criterion.

On this basis we must discriminate between the truth of samvrti (samvrtisatya), and conventional error (mithyā), or what Candrakirti refers to as "mere samvrrt" (samvrtimātra). ${ }^{30}$ Within each of these two divisions we may further extrapolate two subcategories that can be defined according to the type of pramāna associated with the objects contained in each 
category. This being the case, I have contructed the following table which provides an outline of the various types of samvrti implicitly recognized by Candrakīti:

I. False samvrti (mithyāsamvrti, or saṃrịtimätra) General characteristics of the class (first three pramāna-s)

(a) mere words (śabdamätra)

(b) philosophical concepts

(i) Buddhist dogma

(ii) Non-Buddhist dogma

(fourth pramāna: pratyakșa)

(c) impaired perception (mrșädarśana)

hallucination, mirage, distortions due to an optical defect

(d) meditative visualizations skeletons visualized during aśubhamanasikära ${ }^{32}$

II. True samvrti (samvrtisatya)

General characteristics of the class (first three pramäna-s)

(a) objects of veridical mental cognition

(fourth pramāna: pratyakṣa)

(b) objects of veridical sense perception

Specific example

"I" or "ego" (ahamkkāra) $)^{33}$ as agent or patient in mundane affairs (i.e. as founded on the skandha-s)

mundane entities (form, sound, odor, taste and tactile phenomena)

Now let us attempt to establish a few generalizations on the basis of this chart. The subdivisions according to pramanna were made in order to facilitate enquiry into the criteria for distinguishing truth from error at the level of samvrti. In general, Candrakirti's view of the matter seems clear enough - for him any conventionally real object is "real" only insofar as it is acknowledge to exist within the socio-linguistic nexus of cause and effect which constitutes samvrtisatya. ${ }^{34}$ What this means is simply that every real phenomenon is both an effect founded on a particular collocation of 
causes and conditions, and a cause or condition with respect to the other phenomena which serve as its own effects. Assuming for the moment that this quality of efficacy is indeed the sole criterion for membership in the class of conventionally real objects, we will proceed to judge the types of samvrrti mentioned above using it as our standard.

(1) Samvrtisatya. It is obvious that any object of veridical sense perception can be accounted for in terms of its efficacy within some cause-effect continuum: e.g. the son is an "effect" as produced from his father and mother, and a "cause" when, as an adult, he becomes the progenitor of his own offspring. The same standard also seems to apply in the case of objects of valid mental cognition. The conventionally valid notion of a self or ego is founded on cognition of the psycho-physical constituents (skandha-s); which is to say, the ego is an effect produced from the particular collocation of causes and conditions represented in the Buddhist analysis the body, consciousness, feeling, apperception and the predispositions. If this definition of the ego seems to reduce the individual personality to a mere tautology, then we should note that this is in some sense precisely the point: the self is recognized as an effect because it is produced from the psycho-physical constituents as cause: and the psycho-physical constituents are a cause, in this context, to the extent that they are reponsible for production of the concept of "self" as their effect. The same is of course true for all other phenomena:

When the carriage does not exist then the "possessor of parts" does not exist and neither do the parts themselves. ${ }^{35}$

And furthermore, from the auto-commentary:

Composite phenomena which are characterized by the false [appearance of] intrinsic being are produced in dependence on the error of ignorance. For example, the sprout which is characterized by the false [appearance of] intrinsic being is itself produced in dependence on a seed which is also characterized in the same way. Likewise, one should understand that all things whatsoever, as causes and effects, are characterized by the false [appearance of] intrinsic being. ${ }^{36}$

(2) Mithyāsamvryti. Types I.c and I.d contain objects perceived by means of a sense faculty that is somehow "impaired". This impairment can be the result of internal factors like disease (e.g. ophthalmia) or temporarily induced meditative visualizations; or the result of external factors like a mirage or a magical illusion. In any case, these objects are false because they 
do not possess any efficacy within the causal nexus defined by objects of veridical sense perception. As regards the objects included within types I.a and I.b, each of them is in its own way outside the scope of any conceivable causal continuum by definition. Such objects are defined as mere concepts that have originated in mental defects stemming from faulty logic or wrong beliefs that may or may not have been cultivated through speculative philosophy. ${ }^{37}$

\subsubsection{Concluding remarks with respect to samvrti. Candrakīrti briefly characterizes the nature of samvrtisatya, or conventional truth, in Madhyamakāuatāra, VI.158-59:}

Even though the [existence of the carriage] must remain unproven ... either in reality or in the context of mundane experience, nevertheless here in the world it is designated in dependence on its parts, without critical analysis.

This very [carriage] is a possessor of parts and pieces, it is referred to in the world as an "agent", and for common people it is even established as the appropriator (upādatr). Do not lose touch with the screen taken for granted by the world.

It is clear that samvrti is not to be dismissed as totally unreal, since phenomena are real insofar as they interact with each other as cause and effect. Therefore, when samvrti is referred to as illusion (mäyā) this does not so much emphasize the unreality of the world as it does the fact that one may not validly reify the objective referent posited by a word or concept. According to Candrakīrti, entities cannot legitimately be described through recourse to reified concepts of "reality" and "unreality", since these notions and all others are valid only within the context of samvrti. "Meaning" is defined solely in terms of relationship, and for this reason, to reify the concept of reality or unreality by extracting either one from the context of its relationship with the other is to deprive it of any possible meaning.

\subsection{Paramärthasatya}

We have now gained some insight into the realm of mundane experience, where notions of "existence" and "non-existence" or "real" and "unreal" may legitimately be applied, but when it comes to the sphere of paramätha the situation is quite different. All teachings of the Buddha are said to be nothing more than various means towards the understanding of ultimate truth, and for this purpose he necessarily availed himself of language which 
is, properly speaking, viable only in the context of samvrti. Candrakirti explains this technique in the following way:

What is the characteristic of this reality which one may gain access to through the teachings of the Blessed Ones? We have already stated [in Madhyamakaśastra, XVIII.7] : "When that which is to be named is no more, then the sphere of [conceptual] thought must also cease." When this is the case, then what more can be asked? Nevertheless, even though this is so, still, in conformity with conventional truth one accepts mundane notions of "real" and "unreal" and so forth, and attributes characteristics to reality (tattva) by a process of imputation (samäropatah). ${ }^{38}$

\subsubsection{General characteristics of the Ultimate Truth. At first glance, the} concept of ultimate truth seems to represent everything that samvrti is not:

(1) Paramärtha is complete clarity, it is the removal or cessation of obscuration..$^{39}$ It is that which "makes sense" in that it does not appear to be other than it really is. ${ }^{40}$ It is reality (tattva), not as opposed to unreality, but either as (a) the direct vision of things as they truly are (yathäbhütadarsana); or (b) the total destruction of reified conceptual constructs particularly those embodied in the notions of "I" and "mine" - which is accomplished through immediate awareness that no ultimately real substance is ever apprehended either in association with living beings or with insentient objects. $^{41}$

(2) Paramärtha is tranquility or peace (șänti), in the sense that it represents the cessation of ignorance and all the other afflictions. This is paramārtha as nirvāna. ${ }^{42}$

(3) Paramārtha is the absence of all reifying thought (nirvikalpa); ${ }^{43}$ it is the end of the process of assigning labels and the end of the labels themselves; it is the termination of subject and object. It is the cessation of worldly affairs, since the transactional sphere of mundane experience is not possible in any ul timate sense. ${ }^{44}$

(4) Paramārtha is not dependent on anything other than itself. ${ }^{45}$ It neither arises nor does it perish. ${ }^{46}$ Paramärthasatya is emptiness (śūnyatã). The meaning of emptiness is "the absence of intrinsic being" (nihsvabhäva), and this absence of intrinsic being is, as we shall see, directly perceived by the yogi as a characteristic of samvrti as well as of paramärtha. ${ }^{47}$

3.2.2. Paramärtha as the yogic vision. Presumably, even if paramārtha is not an ultimately real substance still this long list of attributes must pertain to 
something, and there is ample evidence in the writings of Candrakirti to attest to the fact that this "something" is actually an attitude towards the world - an attitude embodied in the yogi's direct vision of things as they are. I will now review the evidence for this claim, and clarify what is meant by the expression "direct vision".

In his Prasannapada Candrakirti states that the ultimate truth is pratyātmavedya âryānām, ${ }^{48}$ which seems to indicate that although paramärtha can be obliquely designately through signs and symbols, still it must ultimately be known in and through itself in the individual experience of the saints. ${ }^{49}$ In the auto-commentary to his Madhyamakāvatāra, Candrakirti again explains that "the ultimate meaning (paramärtha) for the Buddhas is just that intrinsic nature (svabhāova; i.e. emptiness) and although it is paramärthasatya ... still each must individually come to know it on his own." ${ }^{50}$ Moreover, it is not only the Buddhas and the saints who can know the ultimate truth in this way, for Candrakirti continues:

Having taught about samvrtisatya, the author desires to teach about paramärthasatya. However, because it is inexpressible and not within the sphere of [conceptual] knowledge, so it is impossible to teach of it as if it were a "thing" (bhävatah). Therefore, he will provide an example for those who want to learn, so that they may illuminate its intrinsic nature through their own personal experience (ran gis myon ba ñid du). ${ }^{51}$

Candrakirti's willingness to "provide an example for those who want to learn" is justified by no less a personage than Nāgārjuna himself:

The ultimate truth cannot be taught without relying on convention, and without understanding the ultimate truth nirvana will not be attained..$^{52}$

Nevertheless, if the ultimate truth must eventually be known through direct realization, then what exactly is the role of the siastra-s in this process? Candrakirti authorizes his career as a philosopher with an unusually candid admission of the limitations of his own knowledge:

The yogis have directly perceived entities in this way (i.e. as devoid of intrinsic being), and we others who desire to obtain the wisdom of the yogis have our highest aspiration directed towards those words that explain the intrinsic nature of phenomena. Although we do engage in explanation of the absence of intrinsic being in entities, still this is done through the medium of philosophical treatises like this one which is infused with the wisdom of the yogis. These words are not dependent on my own ideas, since my eyes are still covered over by the cataract of ignorance. ${ }^{53}$

This passage is interesting not only as an all too rare display of humility, 
but also because Candrakirti seems to be defining "the wisdom of the yogis" not as perception of some particular object, but as a mode of seeing all phenomena: "The yogis have directly perceived all entities in this way ('di ltar gzigs sin)." This mode of seeing phenomena is elsewhere referred to as "non-seeing". ${ }^{4}$ In fact, so far as I know, emptiness is nowhere defined as an object of knowledge (jñeya), but only as "the direct seeing of phenomena as devoid of intrinsic being". ${ }^{55}$ Apparently the yogi does see the things of the world, but he does not see them in the same way as the non-yogi seems them, since the yogi's perception of things is not grounded in reified concepts concerning the ultimate reality or unreality of conventional objects.

We will have more to say about this later on, but at this point I would like to digress for a moment from our investigation into the system of the two truths and devote some space to examination of the technical term svabhäva, which has already been referred to above both as "intrinsic being" and "intrinsic nature". The concept is particularly important, since a correct understanding of the term svabhāva goes hand in hand with any real appreciation of Mādhyamika soteriology.

\section{THE AMBIVALENT MEANING OF THE TERM SVABHĀVA}

In the following passage from the Prasannapadā Candrakīrti uses the term svabhāva in both of its two very distinct meanings:

What is the quintessential nature (dharmata) of phenomena? Their svabhāva. And what is svabhāva? Original, fundamental nature (prakrti). And what is the original, fundamental nature? Emptiness. And what is emptiness? The absence of any svabhãva. And what is the absence of svabhāva? Suchness (tathatā). And what is suchness? "Being-as-it-is", invariableness, eternal stability.

Already the ambivalence is clear enough, since svabhāva has been equated with the absence of svabhäva. Candrakirti continues with a firm definition of the term:

Whatever is possessed by fire or any other phenomenon that is never produced because it is not dependent on anything other than itself and because it is not artificially fabricated, that is referred to as svabhava.

Svabhāva defined in just such terms could easily be translated as "intrinsic being", which is of course the concept that serves as the primary target for 
all the apparatus of the Mädhyamik dialectic. In this passage, though, Candrakirti also intends for his reader to understand the word in its other sense, as a synonym for emptiness:

What is taken under the influence of the optical defect of ignorance to be, in whatever way, ordinary existence (bhävajäta), becomes, by means of "non-seeing", the object of the saints who are rid of the optical defect of ignorance. That alone is the essence [of phenomena], and it is established as svabhàva for the saints, defined as follows: svabhäva is unfabricated and not dependent on anything other than itself; so it has been established by the various masters, and so it should be understood. This svabhāva ("intrinsic nature") possessed by all entities is in essence unproduced, and therefore, because it is non-existence insofar as it is not really anything whatsoever, it is the absence of any svabhāva ("intrinsic being"). Thus it must be understood that entities do not posses any svabhāva.

Although the double entendre of the term svabhäva defies accurate translation here, still we can quite easily grasp the import of the passage. Svabhäva is defined by Nāgāijuna as "that which is unfabricated and not dependent on anything other than itself", ${ }^{57}$ but this definition can be applied equally well to either of two very different referents.

(1) Svabhäva as "intrinsic being". The concept of intrinsic being is, according to Candrakirti, the primal ontological error which lies at the root of all forms of suffering in the world, since it is the foundation for grasping at the notions of "I" and "mine". Intrinsic being is actually the reification of "relative being", i.e. of "being as opposed to non-being". This is svabhāva either as the speculative concept of non-Buddhist systems, or as the conceptual ground that structures the experience of common, naive people (i.e. non-yogis) in a very profound way.

(2) Svabhäva as "intrinsic nature". Although phenomena do not possess any intrinsic being, they do possess an intrinsic nature. This intrinsic nature is not a "thing" (vastu or dravya), but rather a way in which they are related to each other. It is the circumstance under which all phenomena both arise and perish, and the Mādhyamika characterizes these circumstances as "dependent origination" (pratityasamutpāda). Since all entities arise and perish only in dependence on each other, they do not possess any "intrinsic being", and this is their intrinsic nature of emptiness. It is the simple fact of their appearance in the world - "simple" insofar as it is unelaborated by any concept of an existence that is not the mere reflection of non-existence. This svabhäva as the "object" of the direct vision of Buddhist saints and yogis: it is as much a "way of being" (for phenomena) as a "way of seeing" 
(for the yogi). Let me clarify what I mean here by referring back to Candrakinti once again.

In the section from the Prasannapada quoted above we find another brief description of the manner in which all phenomena become objects of the saint's vision. Being and non-being, reality and unreality, and all other such conceptual dichotomies, are necessarily assigned to the sphere of ordinary existence, where each member of the pair derives its meaning only in contrast to its opposite. "Meaning" or "existence" only in the context of reciprocal dependence is the primary distinguishing characteristic of samvrti ${ }^{58}$ and Candrakirti draws attention to this fact in the following words:

That which exists in dependence on a reciprocal object (or "meaning": artha) does not exist - thus the saints have declared. ${ }^{59}$

And in the auto-commentary to this section:

Just as the existence of "long" is [dependent] on "short", while the existence of "short" is [dependent] on "long"; or the existence of the far bank is [dependent] on the near bank, while the existence of the near bank is [dependent] on the far bank: so it is that whatever is imputed in this way does not have any existence through intrinsic being. 60

Elsewhere, in the Prasannapada, Candrakīti explains the way in which "non-existence through any intrinsic being" is not to be equated with absolute non-existence. "Existent" and "non-existent" are equally untenable as characreristics of the ultimate truth about phenomena. I quote here from the Madhyamakaśāstra, kärika X. 11, followed by Candrakīrti's commentary:

How can a supposedly dependent entity be dependent if it does not exist? On the other hand it does not make sense that an existing entity should be dependent on a dependent entity. (X. 11)

Something called fire depends on something called fuel: it will be dependent on the fuel either insofar as it - the fire - exists or does not exist. If it is non-existent then because of its non-existence it will not, like the horns of a rabbit, be dependent on the fuel.

Again let it be the case that it exists. Then because it already exists, how could it depend on fuel? So not even as existing does it exist in dependence, because that would be meaningless. The case of fuel is to be demonstrated in the same way. ${ }^{61}$

Apparently, the vision of the saint has no object other than this very realm of ordinary existence, which is seen by a sort of "non-seeing". He perceives the things of the world as they are: (1) they are unreal because 
they lack any svabhāva "intrinsic being"); and yet (2) they are real because it is their svabhāva ("intrinsic nature") to arise and cease in the world through the force of dependent origination. This is their emptiness.

\section{THE NEGATION OF SAMVRTI: QUALIFIED OR ABSOLUTE?}

Thus far I have developed a fairly cohesive schematic representation of the system of the two truths. I have examined the problem of "reciprocal meaning" as it relates to the doctrine of dependent origination. Despite the fact that we perceive them as originating and passing away in time, all phenomena which appear in the world are "real" or "unreal" only in the web of cause and effect defined as dependent origination. Each of the twin components in any dichotomy is dependent on the other for its existence, in the case of an entity, or for its meaning, in the case of a concept. ${ }^{62} \mathrm{We}$ are now in a better position to assess the nature of the dichotomy which obtains between paramärtha and samprịti.

\subsection{The Concpet of "dependent Origination"}

The word "svabhäva" is defined as "that which is unfabricated and not dependent on anything other than itself", ${ }^{63}$ and just above we have seen how this definition can be made to apply either to the false concept of reified existence or to the truth of emptiness. In both cases we refer to the distinguishing characteristic of all phenomena, their innermost essence which is "unfabricated and not dependent on anything other than itself". From among the many expressions that are synonymous with svabhāva as the ultimate truth, one of the most important is pratittyasamutpāda, a term which itself embodies a great deal of ambiguity. In the Prasannapada, Candrakirti has this to say about dependent origination:

The Blessed One clearly demonstrated that things arise in dependence on causes and conditions and he rejected the possibility that origination could be without cause, from one cause or from a multiplicity of causes, or that things could be produced from themselves, from what is other than themselves or from both. By this rejection the conventional nature (samvrta-svarüpa) of conventional things is revealed for what it really is (yathäavasthitam): Dependent origination is thus itself conventional (samvrta) because it is not produced through any intrinsic being [even though it appears otherwise to the non-yogi]. From the perspective of the wisdom of the saints, there is in [pratītyasamutpāda] no cessation and no movement . . . Nāgārjuna will expound 
throughout this entire treatise that the characteristics of cessation and so forth do not apply to dependent origination. ${ }^{64}$

Here is a very significant clue to the nature of the relationship between ultimate and conventional truth: paramārtha, as pratityasamutpāda, is itself samvrrti, because it appears as other than it really is.

Thus what should be obvious is here confirmed: the dictotomy of paramārtha and samvrẹti is, like all dichotomies, simply another aspect of conventional truth, and therefore the unqualified negation of samvrti on any grounds whatsoever must necessarily constitute an equally unqualified negation of paramārtha. This fact must carry with it rather profound implications with respect to the system of the two truths, and yet I have been unable to find any passage either in the Prassanapada or in the Madhyamakāvatära where these implications are clearly spelled out and discussed in satisfying detail. Moreover, as I mentioned earlier, on reading Candrakirti one is after all still left with the lingering suspicion that the world is somehow absolutely rejected from the perspective of the ultimate truth. Before closing, we must turn for one last look at a few especially problematic themes.

\subsection{The Use of Metaphor and Simple to Describe the Yogic Vision}

One very common motif in both the Prasannapadā and the Madhyamakāvatāra is the use of metaphors and similes in which the world is equated in one way or another with an illusion. We may take the simile of the mirage as an example of the type: Under certain conditions the slanting rays of late afternoon sunlight can produce the impression of clear, blue water; but for those who are nearby, the situation is quite different. Here samvrti is compared with the mirage. Is this an unqualified rejection of apparent phenomena? I quote from the Prasannapadā:

Similarly, those who are far removed from seeing the reality of these things called "I" and "mine" as they are, who tread the path which leads through the cycle of birth and death, they are under the sway of the error of ignorance and so for them [ the self], which is imputed onto the psychophysical constituents, appears as if it were real (satyatah) even though it is definitely a false object (mrșärtha eva); but for those but for those nearby who see the reality of these things, [the self] does not appear as if it were real. 65

In another very frequently used simile the appearance of conventional phenomena is compared to the visual distortions caused by certain forms 
of optical disease. This time I refer to the auto-commentary of the Madhyamak̄̄vatāra:

Suppose that a man with diseased eyes is holding a bone white vase in his hand, and under the influence of an optical defect he sees what appear to be clusters of hair on the surface of the vase. He wants to remove the hairs and so begins to shake the vase when a second man with normal vision happens to pass by. Puzzled as to this odd behavior, the second man approaches and begins to stare at the place where the hairs should appear. Naturally, he apprehends no such hairs and consequently he forms no conception of existence or non-existence, of hair or non-hair, nor even of darkness or any other attribute with respect to these hairs. When the man with an optical defect tells the second man about his idea that he sees hairs, then the second man may desire to clarify this misconception by stating that the hairs do not exist. This is indeed a statement of negation, however the speaker has not in this case maligned [any conventionally real entity]. The man without any optical defect sees the reality of the hairs, while the other man does not. In just the same way, there are those who are striken with the optical defect of ignorance so that they are incapable of perceiving what is real; the intrinsic nature of the skandha-s, dhätu-s and ayatāna-s which is apprehended by them is simply a [false] conventional form. The Blessed Buddhas, however, are without any trace of ignorance so that they perceive the hairs in the manner of one who is not afflicted with an optical defect; that is, the intrinsic nature of the skandhas and so forth seen by them is the ultimate truth of these things. One may ask how it is that they are capable of seeing an intrinsic nature like this, which is invisible. - True, it is invisible, but the fact is that they "see" it by means of "non-seeing". 66

In the first of these two passages the concept of a "self" is compared to a mirage, and in the second, the intrinsic nature of the skandha-s and so forth which is perceived by ignorant people is compared to the illusory appearance of hairs created by an optical defect. If we do not pay very close attention to the inner structure of these similes, then we may be led to conclude that the appearance of samvrti is absolutely false, yet such a conclusion would leave several apparent discrepancies unresolved.

The first example is relatively easy to explain: The mirage appears to be real only for those standing at a distance, but for those who understand the mechanism involved, "it does not appear as if it were real". The concepts of "I" and "mine" are like a mirage insofar as they possess no ultimate reality; however - and this is of critical importance - within the context of samvrti, as we have seen, these concepts are causally efficacious, and to this extent they are quite different from the mirage which is unreal even at the conventional level. It is evident upon closer inspection that the simile here is valid and useful only to a certain point. 
The second example is slightly more subtle. In commenting on this particular simile, Candrakirti makes the following observation:

Those with an optical defect see hairs, flys, and gnats and other such things which are not real; and although they are instructed by those with unimpaired vision, still, unlike these other people, they themselves are not able to realize the true nature of the hair as it really is, by simply not seeing it. On the contrary, on the basis of the instruction they have received from those with unimpaired vision, they develop a merely theoretical grasp of the fact that the hair is false. When, however, their eye of awakening is annointed with the salve of the direct vision of emptiness, which cures any optical defect, and they develop an understanding of reality, then these people realize for themselves the reality of the hair - by not realizing it. ${ }^{67}$

In interpreting this second example we must be especially careful to note that the hairs are compared with the intrinsic nature of conventionally real things like the skandha-s and so forth, and not with the skandha-s themselves. Thus the simile must be explained in this way: Just as the hairs are falsely imputed to the surface of a conventionally real vase, so a quality of intrinsic being is falsely imputed to apparent phenomena which are themselves only conventionally real. And just as the truth of the hairs is "seen by non-seeing", so the intrinsic nature of all conventionally real phenomena is "realized by non-realization". 68 There is neither something, nor nothing, to realize.

\subsection{The Defense of Samvrti}

This mysterious ambivalence with respect to the ontological status of samvrti permeates Candrakirti's work. There are places where he seems to be rejecting samvrti outright, and in still other passages he rushes in to protect samvrti from unqualified negation. In the auto-commentary to the Madhyamakävatära he plainly states that paramärthasatya is not used to negate that which is taken for granted within the context of mundane experience. ${ }^{69}$ If someone is concerned because his property has been stolen then we are told that the Mādhyamika philosopher does not try to console him with the assurance that "all property is of the substance of a dream", since such statement would not be in accord with what is given in mundane experience. ${ }^{70}$ In one of his lighter moments Candrakīrti chides his opponent, the Vijñānavādin, with the following invitation:

If mundane experience does not contradict you, then go ahead and reject the things of this very world. Quarrel with the world if you want to, and afterwards I will side with winner. ${ }^{71}$ 
According to Candrakīrti the Mādhyamika would not presume to interfere with the business of the world:

Because we maintain that [cause and effect] are like magical illusions, therefore no faults accrue to us and the entities of the world are left intact.72

Time and time again throughout chapter six of the Madhyamakāvatāra Candrakirti rises up in defense of samvrti as though it were his own wife: he himself can abuse and malign her, but woe be unto anyone else who might dare to suggest that she is not without fault. In fact, he actually goes so far as to accuse his opponents of being the true nihilists:

On account of his passion for a real substance, inherent in our opponent's view, all the ordered conditons taken for granted in mundane experience have been laid to waste. ${ }^{73}$

\subsection{The Yogi's Attitude Towards Samvrti}

We have already seen that samvrti can serve either as the object of mundane perception or as the sphere of the saints and yogis (äryänäm vișayam). Candrakirti does not attempt to describe the experience of the yogi who directly realizes the ultimate truth, but he does tell us something about the response of the yogi to this "direct seeing" of things as they are:

When the yogi realizes that samvrtisatya is set up through mere ignorance and is devoid of intrinsic being, understanding that emptiness is the characteristic of paramārtha immanent within samvrti, he does not fall into the extremes of dualism. He does not say to himself, "What once was, now is no more", and then go on to accept nihilism after not apprehending any intrinsic being within entities. He does not reject worldly convention which is like a reflected image, nor does he reject [the elements of mundane experience like] karma and its fruits, or the distinction between that which is right and that which is wrong (dharma and adharma). And finally, he does not reify paramärtha by imputing a quality of intrinsic being to [any or all] entities, because he sees that things like karma and its fruits abide within objects that are devoid of intrinsic being, and not within objects that possess intrinsic bieng. ${ }^{74}$

\section{SUMMARY AND CONCLUSIONS}

Our investigation has come full circuit here, and we return now to the question posed by Madhyamakasāstra XXV. 19: What does it mean to say that nirvāna and samsāra are not at all different? Candrakïrti himself supplies a rather succinct response to the puzzle when he writes, "samsāara and nirvãna are of the same essence because both are by nature at peace". ${ }^{75}$ The calm that 
lies at the center of the storm of birth and death is revealed only to a select few, however, and these are the yogis who take samsara as the object of their "non-seeing".

Candrakirti insists that the yogic experience is "the end of the process of assigning labels and the end of the labels themselves". At this point I feel confident that this statement ought to be interpreted in two ways: First, it should be regarded as a hyperbolic device used by the Mādhyamika to drive home his claim that emptiness is a "non-referring" term, or, in the language of Professor Daye, a "third-order capstone reflexive concept". ${ }^{76}$ Therefore, it would be improper to reify the concept of emptiness, forcing it to serve as the ultimate truth about any privileged representation within the mind or any object "out there" in the world. Second, and perhaps more important, such an assertion stresses the significance of a certain attitude towards mundane experience. All phenomena appear "empty" to the yogi who has completely internalized the dialectic of the Mādhyamika, and in this sense "emptiness" is both a "way of being" and a "way of seeing":

That which, taken as dependent or conditioned, is of the nature of birth and death, is, taken as non-dependent and unconditioned, declared to be nirvanna. ${ }^{77}$

Nirvāna is emptiness, ${ }^{78}$ and emptiness is understood as the direct realization of the absence of intrinsic being within all phenomena. ${ }^{79}$ The absence of intrinsic being is not to be equated with non-existence but rather with dependent origination, ${ }^{80}$ and dependent origination is all that there is to mundane experience. ${ }^{81}$ Therefore the key to the relationship between samsära and nirvāna, or samvrti and paramärtha is to be found in the formula of dependent origination; and because dependent origination is the mark of both conventional and ultimate truth, it is the Middle Way:

A chariot is designated in dependence on its parts, the wheels and so forth. Whatever is designated in dependence on its own parts is not produced through any intrinsic being, and the non-production through any intrinsic being is emptiness. Emptiness, defined as non-production through any intrinsic being, is itself the Middle Way. That which is not produced through any intrinsic being cannot possibly be existent; and yet because it lacks non-being neither can it be non-existent. Therefore, on account of its avoiding the two extremes of being and non-being, emptiness, defined as nonproduction through any intrinsic being, is called the Middle Way, or the Middle Path. So it is that the following expressions are various synonyms for dependent origination: emptiness, dependent designation, and the Middle Way. ${ }^{82}$

Paramārtha, as emptiness or dependent origination, is the intrinsic 
nature of all particular phenomena; yet if this intrinsic nature is taken to be an object set apart from the context of its relationship to those phenomena, then it loses any possible meaning, because no characteristic can be understood apart from the object(s) which it characterizes. ${ }^{83}$

What is called samvrti is not pure samvrti, insofar as its intrinsic nature is paramârtha; and at the same time, what is called paramärtha is not pure paramärtha since it is of the nature of pratityasamutpäda to appear as samvrti. ${ }^{84}$ Neither of these two concepts can be isolated from the other and reified into "absolute truth without reference to error", or "unmitigated error without reference to truth". Like the components of any other dichotomy, paramärtha and samvrti require each other in order to yield any meaning. This seems to indicated that for the Mādhyamika the world is now and must always remain a mixture of truth and error, and this might easily prove to be the most profound insight expressed through the dichotomy of the two truths: Paramärtha is a reference to apparent phenomena - it refers to the particular way in which phenomena appear to the yogi - and the term can have meaning only so long as there are apparent objects and a perceiving subject.

At the close of the last chapter of his Prasannapada Candrakirti quotes the following two lines from an unidentified source:

It was taught by the Lord of the world that nirvāna is no nirvāna; A knot tied by space is undone by space. ${ }^{85}$

The knot is tied when the categories of "real" and "unreal" are reified; and it is untied, that is, samsära becomes nirväna, when each one of these concepts is seen to be meaningless in and of itself. I do not see how we could interpret Candrakirti as saying that the world either does or does not ultimately exist; nor could it be justifiedly claimed that its ontological status is in any way actually altered when the world becomes the object of the yogi's direct vision. Presumably, this is why Candrakirti is able to claim that "in nirvanna there is no extinction of anything whatsoever, nor any cessation of anything whatsoever. Nirvaña is in essence the complete disolution of reifying thought." ${ }^{86}$

According to Candrakirti the world is something more than our misconceptions about it, since dependent origination is not itself merely a misconception. This being so, the question still remains: Just what is the ontological status of the world; and when the distortion created by reifying thought is eliminated, what is left of mundane experience? This question brings us around again to the issue of "dependent designation" (prajñaptir upādāya), which was taken 
as the point of departure for this essay. In his Madhyamakävatära, Candrakinti cites this expression as one of the synonyms for pratītyasamutpāda: ${ }^{87}$

A reflection that is mere designation is founded on a collocation of [causes and conditions] including the face and other things which themselves exist as mere designations; a house is designated as dependent on its beams and other structural components which are also mere designations; and a forest is similarly designated as dependent on trees. Just as in a dream one apprehends a sprout that is unproduced through any intrinsic being, so it is equally reasonable that no entity exists apart from its own designation; and this designation is founded on [a collocation of] other entities which are themselves mere designations..$^{\mathbf{8 8}}$

There is no question about the fact that our experience is shaped to a very great extent by our conceptual frames, yet it is difficult to determine just how deeply our perceptions of a given situation (and the actions based on them) are grounded in these patterns of thought. This is an issue of the utmost importance primarily because these conceptual frames supply most, if not all, of the meaning and structure that determines our motives and so guides our behavior in the course of daily life. Moreover, it is clear that many of the concepts which govern our acts are in themselves quite abstract and almost wholely dependent on other concepts from which they derive their meaning. The mechanism is illustrated quite graphically in a recently published study of metaphorical thought: 89 If we did not at some level structrue our concept of "argument" through the metaphor of "war", then would we still "attack our opponent's position", or "retrench and defend" our own? Our behavior under such circumstances is obviously shaped by the metaphorical application of a second concept, and yet, must we necessarily think in terms of "winning" or "losing" an argument, or could the experience defined by the concept of "argument" be conceived of in an altogether different way, perhaps as "dance" rather than as "war"? If both participants were to conceive of argument through the metaphor of "dance", then we might assume that their behavior would be governed by a desire to establish understanding through balance and harmony, rather than through victory and defeat.

This process of structuring one concept in terms of another, layer after layer, most certainly exerts a profound effect on the overall pattern as well as the details of our experience. In the study cited above, the authors have done an excellent job of laying bare this innate tendency of conceptual thought. However, if the Mādhyamika analysis is correct, they overlook what may be the most deeply rooted and pernicious of all metaphors: "reality as substance". 
What does it mean to conceive of the ultimate truth as "dependent origination" rather than as a substance - whether it be a privileged representation within the mind, or a real external object? The non-referential theory of language and conceptual thought, embodied in all the apparatus of the Mãdhyamika dialectic, entails two primary consequences:

(1) It serves to enforce the strictly pragmatic use of words and concepts in a given socio-linguistic matrix; and

(2) It acts as a safeguard against any tendency towards the application of words or concepts to private objects supposed to lie outside this sociolinguistic matrix; or, in the jargon of the Mâdhyamika, it brings an end to "conceptual diffusion" (prapañca).

In the context of Western philosophy, a very similar non-referential theory of language is associated with the name of Ludwig Wittgenstein:

We may say that the general criteria by which the later Wittgenstein judges philosophical utterances to be nonsensical is the pragmatic criterion of meaning. This is shown by his submitting philosophical statements to questions such as: "What use can we make of that statement?" "What practical consequences is it supposed to have?" "Under what circumstances, to achieve what, would you say that?" 90

This approach to language and conceptual thought not only represents the theoretical statement of a particular philosophy, but moreover, it necessarily implies a subtle, yet highly significant paradigmatic shift in the purpose of philosophizing. If the meaning of words and concepts is to be judged by strictly pragmatic criteria, then the value of philosophy itself can no longer be measured solely - or even especially - in terms of its success as a finely tuned system of abstract, logical propositions. This is certinaly not to suggest that scholastic or academic viability is not essential to any philosophy; it is simply to point out that, given this particular view of language, academic success alone would not only constitute a rather hollow philosophical victory, but a meaningless one as well. Like the Mãdhyamika, Wittgenstein also seems to have been essentially motivated in his work by a very pragmatic sense of purpose, a purpose which lay not in explaining the nature of reality so much as in changing our attitude towards the world of mundane experience:

I am in a sense making propoganda for one style of thinking as opposed to another. I am honestly disgusted with the other ... Much of what I am doing is persuading the people to change their style of thinking. 91

We might rephrase the question posed just above and ask: What would it 
mean to live in a world where one's concepts were no longer structured in a very crucial way by reified notions of "reality" and "unreality"? I submit that the overriding concern here is neither ontological nor epistomological after all, for, reflecting on these questions, I am once again reminded of Candrakirti's assertion that one is lost if he does not understand the purpose of emptiness, which is "the tranquilizing of all conceptual diffusion".

Liberation follows from the destruction of both karmic action and the afflictions. Karmic action and the afflictions arise from reified notions [of real and unreal things], and these are produced from conceptual diffusion. Conceptual diffusion, however, ceases in emptiness..$^{92}$

Unlike either a strictly rational philosophy or a metaphysical system, the Mãdhyamika does not seem to be preoccupied with sophisticated epistomological or ontological explanations of reality. On the contrary, the dialectic is apparently designed to expose the meaninglessness of any such attempts at explanation, and in doing so, to "make propaganda" for a style of thinking that should lead to a conception of ultimate truth as duhkha-nirodha, or the cessation of all suffering, by altering one's attitude towards everyday experience in this world.

Department of Far Eastern Language and Literature, University of Michigan.

\section{NOTES}

1 PP, p. 135.

2 Ibid., p. 373.

3 MS, XVIII. 9.

4 PP, p. 11.

5 Ibid., p. 135.

6 Ibid.

7 Ibid., p. 4.

8 Daye,p. 96.

9 Ibid., p. 95.

10 Ibid., pp. 92-93.

11 Crittenden (see bibliography).

12 Ibid., pp. 328-29.

13 Ibid., p. 327.

14 MA, pp. 218-19.

15 MS, XXIV. 1.

16 Ibid., XXIV. $5 \mathrm{~cd}$. 
17 Ibid., XXIV. 7.

18 PP, pp. 990-91.

19 MS, XXIV. 9.

20 MA, VI. 23.

21 PP, pp. 492-93.

22 MA, VI. $28 \mathrm{ab}$.

23 PP, p. 58.

24 Ibid., p. 54.

25 Ibid., p. 75.

26 Ibid.

27 Ibid.

28 MA, p. 113.

29 See section five of this essay.

30 MA, VI. 28.

31 Ibid., VI. 84 and VI. 92.

32 Ibid., VI. 69.

33 Ibid., VI. 162.

34 See for example the following verses along with Candrakirti's commentary on them:

MA VI. 33; VI. 35; VI. 100; VI. 159; VI. 196; VI. 197.

35 MA, VI. $161 \mathrm{ab}$.

36 Ibid., VI. 156.

37 Ibid., p. 104.

38 PP, p. 372.

39 Ibid., p. 538.

40 Ibid., p. 41.

41 Ibid., p. 340.

42 Ibid., p. 41.

43 MS, XVIII. 9.

44 PP, p. 493.

45 Ibid.

46 Ibid., p. 524.

47 MA, p. 218.

48 PP, p. 493.

49 See Edgerton, p. 376.

50 MA, p. 108.

51 Ibid., p. 109.

52 MS, XIV. 10.

53 MA, pp. 218-19.

54 Ibid., p. 111.

55 See for example, PP, p. 351.

56 PP, pp. 264-351.

57 PP, p. 511.

58 PP, p. 68.

59 MA, VI. $58 \mathrm{~cd}$.

60 MA, p. 150; also see MS, X. 10-11.

61 Sprung, p. 138.

62 Artha carries both an epistomological and an ontological significance.

63 See note 57. 


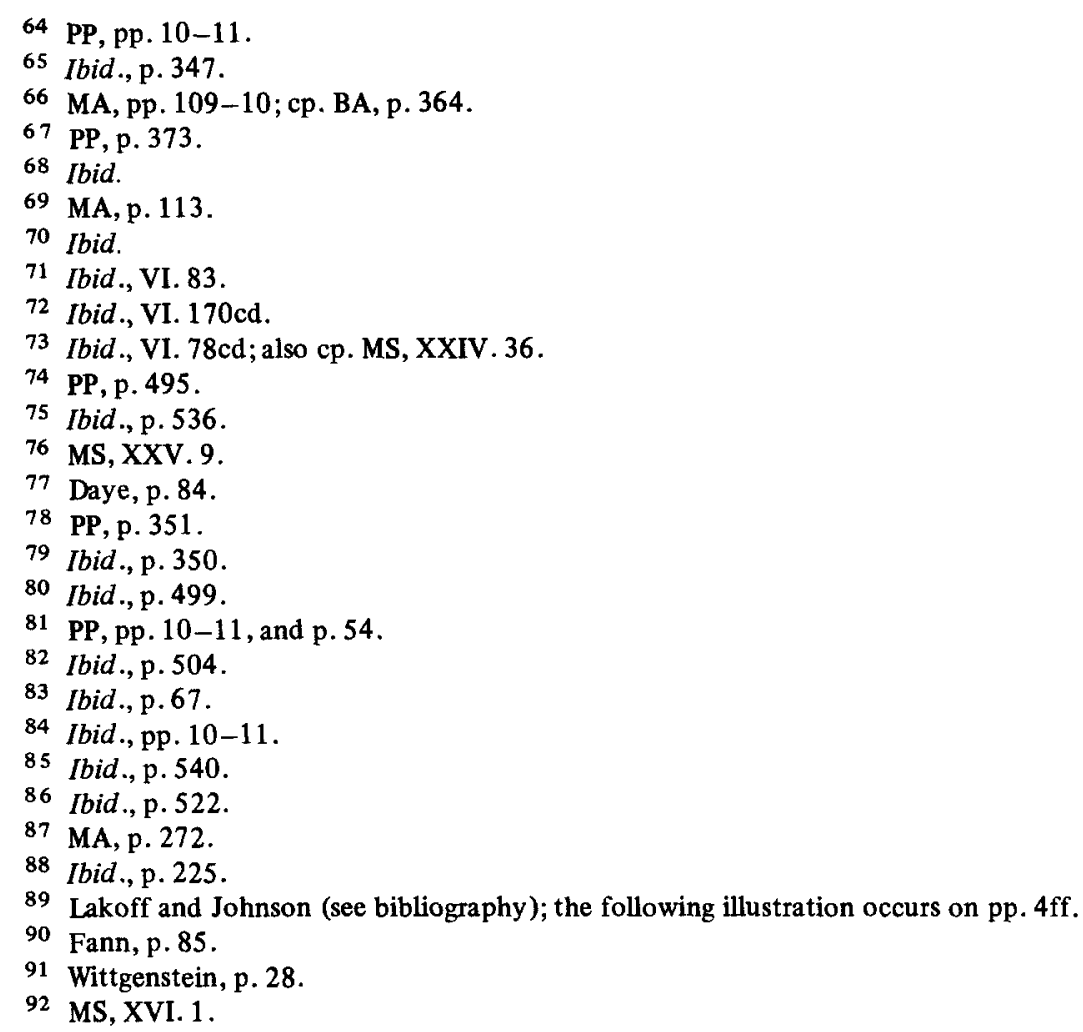

\section{BIBLIOGR APHIC ABBREVIATIONS}

BA Bodhicaryāuatāra

MA Madhyamakãvatära

MS Madhyamakaśästra

PP Prasannapadā

\section{BIBLIOGRAPHY}

Crittenden, Charles (1981). 'Everyday Reality as Fiction: A Mādhyamika Interpretation', Journal of Indian Philosophy 9: 325-333.

Daye, Douglas (1975). 'Major Schools of the Mahāyāna: Mādhyamika', Buddhism: $A$ Modern Perspective, edited by Charles Prebish: 76-96.

Edgerton, Franklin (1953). Buddhist Hybrid Sanskrit Dictionary. New Haven: Yale University Press. 
Fann K. T. (1971). Wittgenstein's Conception of Philosophy. Berkeley and Los Angelos: University of California Press.

Lakoff and Johnson (1980). Metaphors We Live By. Chicago: University of Chicago Press.

La Vallée Poussin (ed.) (1902-1914). The Bodhicaryävatära of Santideva with the Panjika of Prajnakaramati. Calcutta: Bibliotheca Indica.

La Vallée Poussin (ed.) (1908). The Madhyamakävatära of Candrakīrti with the author's bhâsya. St. Petersburg: Bibliotheca Buddhica, Vol. IX.

La Vallée Poussin (ed.) (1912). The Madhyamakašāstra of Nāgãrjuna with the Prasannapadā of Candrakīrti. St. Petersburg: Bibliotheca Buddhica, Vol. IV.

Sprung, M. (transl.) (1979). The Lucid Exposition of the Middle Way. Boulder: Prajñã Press.

Wittgenstein, L. (1953). Lectures and Conversations. Berkeley and Los Angelos: University of California Press. 